\title{
CHOCOLATE CHICKEN CHEESECAKE
}

\section{A taste of success.}

\section{BY M. J. PETTIT}

$\mathrm{B}$ ryant bit his lip as three-Michelinstarred chef Jean Christophe assessed the evening's final plate. The pinkish meat, coarsely butchered, sat in a pool of steaming liquid. Chef bent over and wafted the aroma, catching himself before he recoiled. "Tell us about your dish, Nostradamus."

The avatar's hydraulics hissed as it craned its head into focus, giving the cameras an almost human smile. A rainbow of stains and scorch marks littered its chef's jacket. "I've prepared for you a carnival of chicken and pork sashimi." A pair of icy blue lamplights pulsed as Nostradamus listed the mountain herbs strewn about the plate.

"Bathed in raspberry coulis?"

"I'd call it more of a drizzle, chef."

Chef gave a blackened smear a tentative poke with his fork. "Is this mole sauce?"

"No. My sundrenched mayonnaise got a touch over-ripe but I did have time to plate it this week."

A forkful suspended before his mouth, Chef Christophe shot a pleading look off camera.

"You don't like my dish," the ever-prescient Nostradamus observed.

"No," Chef fumbled for words, "just taking a moment to savour your ... creativity."

"But you haven't tasted it yet."

Bryant squeezed Rita's delicate hand. His beloved for the past three episodes had stumbled about the kitchen ever since her amuse bouche mysteriously turned rancid. It was down to her or Nostradamus. The real mystery was the machine's continued survival given its monstrous palate and brutal technique.

Then Chef Christophe coughed out those impossible words: "Genius, utter genius."

Back in the dorms after kissing Rita goodbye, Bryant decided he needed to confront someone, anyone. He understood now. He was never meant to win. But he wouldn't go quietly. He couldn't. He still had a chance to return for the reunion special as fan favourite.

He found the evening's other runner-up alone, the remaining occupant of Team Virgo's quarters. Sally dangled her legs from the upper bunk as she unwound with a Bud Lite Lime. With her cropped white hair and sinewy frame, she looked like a seasoned warrior. Rumour was she'd once been military, before joining the cast back in season one.

"Too bad about Rita," Sally said. "I'll miss her."

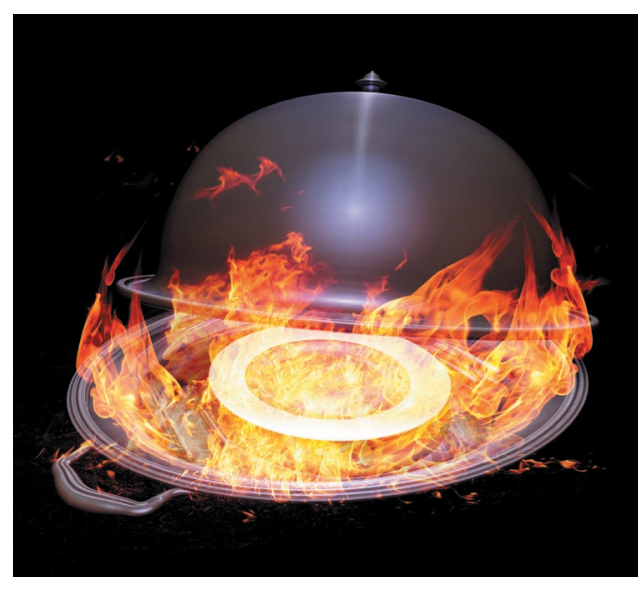

Bryant waved away the phony regret. "I get it now," he said, "why it's so much harder in person than it looks on TV."

"Tell me about it. Nostradamus is one tough cookie."

"But how does it compete without a sense of taste or smell?"

Sally shrugged before taking another slug of her beer. "We're playing against something akin to the Internet. It has to win. You get that, right? Besides, Nostradamus made a great comeback tonight. Such a brave flavour profile."

"They had to pump the guest judge's stomach."

Bryant faced the not-so-hidden camera streaming their conversation for the aftershow fans.

"That could have been anything."

"Rita didn't deserve to get sent home."

"Sorry they eliminated your girlfriend, but she shouldn't have used frozen scallops. Destroys their texture."

"It was a deep-freezer challenge."

"Whatever, man-bun."

Bryant winced. How had that awful nickname stuck? "I've figured it out, why each season starts again with eleven new contestants but keeps the two of you."

Sally shrugged. "We have a history. Nostradamus sees me as its biggest threat. Gets a thrill each time it defeats me."

"That's not it. I saw you sabotaging Rita tonight."

Sally eyed the camera. "Listen kid, Nostradamus held on fair and square."

"You poured boiling water into her ice cream maker. Swapped salt for her sugar while the host distracted her with an interview."

"Not my fault she let the pressure get to her."

"To think I used to root for you," Bryant said. "How much do they pay you to make that machine appear more than human?"

"You don't know what you're talking about."

"Why can't you admit this whole thing is fake?"

"Fine, but what were you expecting? We're on TV."

"Is it true, Sally?" Nostradamus asked. Neither of them had noticed it eavesdropping at the door. "I don't win fair and square."

The avatar's head drooped.

Sally leapt from her bunk to console it, but Nostradamus bolted away.

"Shit," Sally turned on Bryant. "You couldn't drop it, could you?"

"No, I came into this competition looking to win."

"Really? After 18 seasons, you thought I'm going to defeat Nostradamus. It's the most powerful consciousness on Earth."

"And a terrible cook."

"With an incredibly fragile ego," Sally said. "Think I want to keep competing? We all had our part to play. Even Rita understood that."

"So why mess with her?"

"I couldn't trust the judges. They're only human," she said as she paced the room. "Taking care of Nostradamus was my responsibility."

"I don't get it. You're talented. You could win this thing if you tried. Put an end to it all."

Bryant started in the direction of an unexpected rumble of thunder.

Sally gulped the last of her beer. "I remember when life was simple, when Nostradamus was just a neural net scraping Pinterest boards and food blogs. The first iteration spewed out nonsense recipes like 'chocolate chicken cheesecake."

Bryant watched as the lights flickered.

"It stored the memory somewhere because after self-awareness, Nostradamus declared its intentions to eliminate us," Sally continued. "Thankfully, it meant on a damned cooking show. My superiors could hardly say no, given the circumstances. Kept it distracted from the doomsday scenario. Well, at least until you came along, man-bun."

The dormitory shook with a second thunderclap. Bryant ducked under the bunk as fissures ran down the concrete walls.

Sally sounded resigned as chunks of plaster fell around her. "So how are you feeling about our next judges' table?" -

M. J. Pettit is an academic and writer who divides his time between Toronto, Canada, and Manchester, UK. 